\title{
KONSEP PENDIDIKAN ISLAM PERSPEKTIF AL-GHAZALI
}

\author{
ALWAN SUBAN \\ Universitas Islam Negeri Alauddin Makassar \\ Jl. H.M. Yasin Limpo No. 36 Romangpolong-Gowa, Indonesia \\ Email: alwan.suban@uin-alauddin.ac.id
}

\begin{abstract}
:
The purpose of this article is to analyze the conception of Islamic Education from the perfectives of Al-Ghazali. This article used library research to review Al-Ghazali's thoughts and conceptions on Islamic Education. The results shows that Al-Ghazali had a thorough understanding of Islamic Education. This paper also reveals his thoughts and understanding on education management, managing learners, and managing curriculum. This paper concludes that education according to Al-Ghazali is the process of humanizing humanity until the end of their lives towards a self-approach to God so that they become perfect human beings. Al-Ghazali describes the things that must be fulfilled by students in the learning process: learning is a soul process, requires concentration, must be based on the attitude of tawadhu'. Regarding a curriculum, he paid special attention to the religious and ethical sciences and was based on two tendencies: religious tendencies and Sufism; and pragmatic tendencies.
\end{abstract}

Keywords: Islamic education, Al-Ghazali's thoughts, Perspectives

\section{PENDAHULUAN}

I-Ghozali adalah seorang ulama' besar Islam yang sebagian besar waktunya
didedikasikan untuk memperdalam dan mengkaji khazanah keilmuan.
Perhatiannya yang sangat besar kepada ilmu dan pendidikan menjadikan AlGhazali sebagai salah satu ulama' Islam yang banyak menelurkan hasil buah pemikirannya kedalam bentuk tulisan yang hingga saat ini masih dapat dipelajari serta dianut oleh sebagian kelompok masyarakat (Fathiyana, 2011).

Pada hakikatnya usaha pendidikan menurut Al-Ghazali adalah dengan mengutamakan beberapa hal yang diwujudkan secara utuh dan terpadu karena konsep pendidikan yang dikembangkannya berawal dari kandungan ajaran dan tradisi Islam yang menjunjung prinsip pendidikan manusia seutuhnya. Al-Ghazali adalah tokoh yang sangat revolusioner dan banyak memberikan sumbangan pemikiran tentang pendidikan termasuk dalam pendidikan Akhlak (Setiawan, 2017). Al-Ghazali merupakan ulama sekaligus tokoh pendidikan yang lahir pada tahun 1058 M (Mundiri \& Bariroh, 2018).

Hal ini juga membuat para ahli ilmu baik filosof, agamawan, maupun ahli ilmu kalam dan lain-lain merasa tertantang untuk melakukan penelitian terhadap hasil karya Al-Ghazali. Al-Ghazali merupakan sosok pemikir Islam. Dia ahli dalam bidang 
hokum Islam, Ushul Fiqih, Fiqih, Filsafat, Sufistik, dan Islam. Ketenaran sosok AlGhazali merupakan dimensi yang luas. Bukunya yang berjudul Ihya' Ulum Al-Din merupakan bukti kualitas yang dimilikinya. Tidak hanya itu bentuk pemikirannya yang seperti itu, tetapi juga bentuk argumentasi kontroversial seperti dalam bukunya Tahafu al-Falasifah itu memberikan efek tersendiri bagi kalngan kaum rasionalitas. Upaya al-Ghazali yang melindungi Islam dari pemikiran rasionalitas yang tidak terbatas membuatnya mendapatkan gelar "hujjatul al-Islam" (Wartini, 2015).

Berdasarkan realitas tersebut dapat dipahami bahwa ternyata Al-Ghazali juga banyak memberikan perhatiannya terhadap masalah-masalah pendidikan. Hal ini dilakukan Al-Ghazali mengingat bahwa islam sangat menjunjung tinggi bagi mereka yang memiliki ilmu dan mereka yang dengan sungguh-sungguh mencari ilmu (Ramayulis, 2006).

Di zaman yang modern ini sangat relevan untuk mengetahui konsep pendidikan dari tokoh Muslim terkemuka. Oleh karena itu, artikel ini akan membahas mengenai siapa sesungguhnya Al-Ghazali dan bagaimana konsepnya tentang pendidikan Islam yang meliputi manajemen pendidikan, manajemen peserta didik, dan manajemen kurikulum.

\section{METODE PENELITIAN}

Metode penelitian yang digunakan dalam penelitian ini adalah penelitian pustaka (library research) dengan menggunakan pendekatan penelitian kualitatif. Penulis dalam hal ini berupaya mengumpulkan data-data kepustakaan terkait konsep pemikiran Al-Ghazali terkait pendidikan Islam yang meliputi manajemen pendidikan, manajemen peserta didik, dan manajemen kurikulum baik melalui bukubuku ataupun sumber lain seperti artikel atau penelitian-penelitian terdahulu yang terkait dengan topik tersebut. Kumpulan konsep pendidikan Islam Al-Ghazali kemudian dianalisis isinya untuk kemudian menentukan tema-tema yang terkait dengan konsep pendidikan Islam dalam perspektif Al-Ghazali.

\section{HASIL PENELITIAN DAN PEMBAHASAN \\ Sekilas Biografi Al-Ghazali}

Nama lengkapnya adalah Muhammad bin Muhammad bin Muhamad bin Ahmad Al-Ghazali. Beliau dilahirkan pada tahun 450 H/1058 M, di desa Ghozalah, Thusia, wilayah Khurosan, Iran (Syarif, 2018). Al-Ghazali adalah pemikir ulung islam yang mendapat gelar "pembela islam"(hujjatul islam). Gelar tersebut diberikan kepada Al-Ghazali karena ia seorang yang mengabdikan hidupnya pada agama dan masyarakat (Sulaiman, 1993)

Al-Ghazali memiliki keahlian berbagai disiplin ilmu, baik sebagai filosuf, sufi, maupun pendidik. la menyusun beberapa kitab dalam rangka menghidupkan kembali ilmu-ilmu Agama. Pada dasarnya, buku-buku yang dikarangnya, merupakan upaya untuk membersihkan hati umat Islam dari kesesatan, sekaligus pembelaan 
terhadap serangan-serangan pihak luar, baik Islam maupun Barat (Orientalis). Karena jasanya dalam mengomentari dan melakukan pembinaan pembelaaan terhadap serangan-serangan demikian, maka ia diberi gelar Hujjat al- islam (Abidin Ibn Rusn, 1999).

Sejak kecil, Al-Ghazali dikenal sebagai anak yang senang menuntut ilmu pengetahuan. Karenannya, tidak heran sejak masa kanak-kanak, ia telah belajar dengan sejumlah guru dikota kelahirannya. Di antara guru-gurunya pada waktu itu adalah Ahmad Ibn Muhammad Al-Radzikani. Selain itu ia tidak segan-segan belajar dengan guru-guru di daerah lain yang jauh dari kampung halamannya. Dia belajar tidak hanya di kota Nisyapur tapi juga di Khurasan, yang pada saat itu merupakan salah satu pusat ilmu pengetahuan yang penting di dunia Islam. Dia juga menjadi murid Imam Al Haramain Al Juwaini. Al Ghazali tidak hanya belajar teologi, sufisme, dan Filsafat tapi juga belajar hukum Islam, logika da ilmu-ilmu alam (Syadani, 1997).

Untuk memenuhi kebutuhan intelektualnya, ia kemudian hijrah ke Naisabur dan belajar dengan Imam al-Juwaini. Masa mudanya bertepatan dengan bermunculan para cendekiawan, baik dari kalangan bawah, menengah, sampai elit. Kehidupan saat itu menunjukan kemakmuran tanah airnya, keadilan para pemimpinnya, dan kebenaran para ulamanya. Dunia tampak tegas disana, sarana kehidupan mudah didapatkan, masalah pendidikan sangat diperhatikan, pendidikan dan biaya hidup para penunutut ilmu ditanggung oleh pemerintah dan pemuka masyarakat. Kesempatan emas itu dimanfaatkan oleh al-Ghazali untuk memperoleh pendidikan setinggi-tingginya. Mulu-mula ia belajar agama, sebagai pendidikan dasar, kepada seorang ustad setempat, Ahmad bin Muhammad Radzkafi. Kemudian Al-Ghazali pergi ke Jurjan dan menjadi santri Abu Nashr Ismaili (Zainuddin, 1991, p. 7).

Setelah menamatkan studi di Thus dan Jurjan, Al-Ghazali melanjutkan dan meningkatkan pendidikannya di Naisabur. Tidak berapa lama mulailah mengaji kepada Al-Juwaini, Al-Ghazali belajar IImu Kalam, IImu Ushul, Madzhab Fiqih, retorika, logika, tasawuf dan filsafat. Al-Juwaini dipandang oleh Al-Ghazali sebagai syaikh yang paling alim di naisabur saat itu, sehingga kewafatannya menyebabkan kesedihan yang mendalam baginya. Tetapi akhirnya peristiwa itu mengharuskannya melangkah lebih jauh, ditinggalkanlah Naisabur menuju Mu"askar, suatu tempat atau lapangan luas yang di sana didirikan barak-barak militer Nidhamul Muluuk, perdana menteri saljuk. Tempat itu sering digunakan untuk berkumpul para ulama ternama (Abidin Ibnu Rusn, 1998).

Oleh karena sebelumnya keunggulan dan keagungan nama Al-Ghazali telah dikenal oleh perdana menteri, kehadiran Al-Ghazali diterima dengan penuh kehormatan. Ternyata benar, setelah beberapa kali Al-Ghazali berdebat dengan para ulama di sana, mereka tidak segan-segan mengakui keunggulan ilmu Al- Ghazali karena berkali-kali argumentasinya tidak dapat dipatahkan. Sejak saat itulah AlGhazali namanya tersohor dimana-mana (Bakar, 1997). 
Pada tahun $1901 \mathrm{M} / 484 \mathrm{H}$, Al-Ghazali diangkat menjadi dosen pada Universitas Nidhamiyah, Baghdad. Atas prestasinya yang kian meningkat, pada usia 34 tahun Al Ghazali diangkat menjadi pimpinan (rektor) universitas tersebut. Selama menjadi rektor, Al Ghazali banyak menulis buku yang meliputi beberapa bidang, seperti fikih, ilmu kalam, dan buku-buku sanggahan terhadap aliran-aliran kebatinan, Ismailiyah, dan filsafat (Bakar, 1997). Karir Al Ghazali semakin meningkat tetapi Al Ghazali juga mengalami krisis kebatinan sehingga ia memutuskan untuk menghabiskan sisa umurnya untuk membaca Al-Quran dan hadis serta mengajar. Disamping rumahnya, didirikan madrasah untuk para santri yang mengaji dan sebagai tempat berkhalwat bagi para sufhi (Al-Ghazali, 1969, p. 18). Suatu hal yang menarik dari Al-Ghazali adalah kecintaannya dan perhatiannya yang sangat besar terhadap moralitas dan pengetahuan sehingga ia berusaha untuk mengabdikan hidupnya untuk mengarungi samudra keilmuan.

\section{Manajemen Pendidikan}

Pendidikan merupakan aspek kehidupan manusia yang penting. Tujuan pendidikan Islam adalah menciptakan peserta didik berkompeten dari aspek kognitif, afektif, dan psikomotorik berdasarkan nilai-nilai Islam. Lembaga pendidikan Islam merupakan wadah dan sistem untuk memproses peserta didik dan menciptakannya sebagai pribadi yang unggul. Pengelola lembaga merupakan faktor utama yang melakukan usaha dalam memperbaiki mutu pendidikan di lembaganya (Wahyudi \& Rouf, 2012).

Di kalangan umat Islam juga muncul berbagai masalah kritis tentang pendidikan yang dengan sangat mendesak menuntut suatu pemecahan berupa terwujudnya suatu sistem pendidikan yang didasarkan atas konsep Islam. Salah satu solusi pemecahannya adalah pembenahan manajemen dalam pendidikan. Selain dari ekonomi, budaya, negara, maupun organisasi manajemen mempunyai peran penting untuk mengantarkan kemajuan pendidikan. Untuk meningkatkan mutu dari suatu pendidikan selain melalui peningkatan fasilitas belajar juga harus dilakukan dengan peningkatan manajemen. Dengan demikian manajemen dapat dijadikan resep dalam mengatasi masalah dan kemudian mengembangkan lembaga pendidikan tersebut, dalam hal ini konteks lembaga pendidikan Islam. Demikian manjemen pendidikan Al- Gazali (Wahyudi \& Rouf, 2012).

Al-Ghazali selalu menyandarkan semua pendapatnya dengan dasar Al-Qur'an dan hadis. Kemudian terkadang juga dikuatkan dengan pendapat/hadis sahabat. Contoh yang didasarkan pada hadis yaitu tentang wajibnya mencari ilmu, Al-Ghazali dalam kitab Ihya" Ulum al Din merujuk pada hadis Nabi saw. Mencari ilmu wajib atas setiap muslim. Karena dengan ilmu orang bisa mengetahui tentang rukun Islam dan bagaimana cara melaksanakannya, tanpa ilmu orang tidak mungkin bisa tahu tata cara mengerjakan sesuatu yang diperintahkan dalam hal ini ibadah (Tafsir, 1992, p. 78). Al-Ghazali memandang manusia sebagai mahluk teosentris. Sehingga dia 
menyatakan bahwa tujuan dari pendidikan bukan hanya sekedar mencedaskan pikiran saja, melainkan juga berusaha untuk membimbing, mengarahkan, meningkatkan dan mensucikan hati untuk menghadap kepada Allah (Suryadarma \& Haq, 2015).

Al-Ghazali dalam karyanya Ihya' Ulum al Din dan Bidayat al- Hidayah memosisikan ilmu itu pada posisi yang pertama disebutkan bahwa sebaiknya dalam melakukan sesuatu itu didasari oleh ilmu, ini menandakan bahwa ilmu itu sesuatu yang penting dan harus ditempuh terlebih dahulu. Karena menurutnya datangnya petunjuk itu melalui ilmu terlebih dahulu. Arahan pendidikan AI-Ghazali menuju manusia sempurna yang dapat mencapai tujuan hidupnya, yakni kebahagiaan dunia akhirat. Hal ini berarti bahwa manusia hidup selalu berkedudukan sebagai murid (Nisa', 2016).

Mencari ilmu itu menurut Al-Ghazali harus bersih hatinya dari sifat-sifat yang tercela, agar dalam rangka belajarnya pencari ilmu itu tenang sehingga ilmunya itu mudah untuk diterima. Dilihat dari niatnya dalam mencari ilmu Al- Ghazali mengategorikan tentang orang mencari ilmu itu menjadi tiga:

a. Orang yang mencari ilmu untuk bekal di akhirat. Dalam hal ini pencari ilmu tidak pernah mempunyai niat untuk yang lain, ia hanya semata- mata mencari keridhoan Allah serta mencari kebahagiaan akhirat. Maka baginya termasuk golongan orang-orang yang beruntung.

b. Orang yang mencari ilmu supaya dengan ilmu tersebut ia mendapatkan derajat, pangkat, dan harta. Orang yang mencari ilmu dengan mempunyai niat seperti itu maka ia termasuk apes karena niatnya yang salah, dan dikhawatirkan ia termasuk su'ul khotimah. Hal-hal yang diniatkan itu bisa merusak amalnya.

c. Orang yang mencari ilmu dan ia terkalahkan dengan hawa nafsunya. Ilmunya digunakan untuk memperbanyak harta, untuk menyombongkan diri, untuk mencari jabatan, dan kemuliaan, Golongan ini termasuk golongan orang-orang yang merugi (Fad, 2019).

Ketika asas-asas yang digunakan walau berasal dari bidang-bidang ilmu lain yang diadopsi sesuai dengan pandangan Al-Qur'an, maka hasilnya juga tidak boleh bertentangan dengan apa yang seharusnya diajarkan menurut ajaran agama (Tafsir, 1992, p. 79). Dalam rangka mensosialisasikan nilai-nilai Islam dalam praktik pendidikannya menurut Al-Ghazali tidak harus melalui suatu institusi karena menurut Al-Ghazali guru bisa siapa saja, menurutnya bertanya kepada sesorang tentang suatu hal yang berhubungan dengan ilmu, itu juga termasuk guru.

Al-Ghazali adalah orang yang banyak mencurahkan perhatiannya terhadap bidang pengajaran dan pendidikan. Oleh karena itu ia melihat bahwa ilmu itu sendiri adalah keutamaan dan melebihi segala-galanya. Oleh sebab itu menguasai ilmu baginya termasuk tujuan pendidikan dengan melihat nilai-nilai yang dikandungnya dan karena ilmu itu merupakan jalan yang akan mengantarkan seseorang kepada 
kebahagiaan di akhirat serta sebagai alat untuk mendekatkan diri kepada Allah (Nizar, 2002, p. 47).

Oleh karena itu ia menyimpulkan bahwa pendidikan adalah proses memanusiakan manusia sejak masa kejadiannya sampai akhir hayatnya melalui berbagai ilmu pengetahuan yang disampaikan dalam bentuk pengajaran secara bertahap di mana proses pengajaran itu menjadi tanggung jawab orang tua dan masyarakat. Maka sistem pendidikan itu haruslah mengarahkan kepada tujuan yang jelas.

Tujuan dari mencari ilmu menurut Al-Ghazali tidak lain adalah mendekatkan diri kepada Allah. Dan salah satu dari metode penyampaian ilmu adalah pengajaran. Pendidikan merupakan satu-satunya keutamaan, menyangkut harkat dan martabat manusia, dan menanamkan nilai kemanusiaan. la menyatakan bahwa kemajuan suatu masyarakat atau bangsa sangat bergantung pada pendidikan. Dalam pandangan Al-Ghazali ilmu adalah rangking pertama dalam ibadah. Di samping itu, terkesan kuat bahwa manusia, menurut Al-Ghazali dapat memperoleh derajat atau kedudukan yang paling terhormat di antara sekian banyak makhluk di permukaan bumi dan langit (Abdullah, 2002, pp. 9-19).

\section{Manajemen Peserta Didik}

Menurut Al-Ghazali, peserta didik yang dimaksud ialah murid. Peserta didik menurut Al-Ghazali adalah manusia yang fitrah (Arista, 2019). Beliau menguraikan hal-hal yang harus dipenuhi murid dalam proses belajar mengajar adalah sebagai berikut:

1. Belajar merupakan proses jiwa.

Pada hakikatnya, yang wajib belajar adalah murid sedangkan guru bertugas membimbingnya, berperan sebagai penunujuk jalan dalam belajar. Seorang murid yang belajar tanpa bimbingan atau arahan guru, apa lagi yang dipelajari adalah berbagai disiplin ilmu, bisa jadi ia tidak akan memperoleh ilmu itu, mengingat psikisnya terutama yang menyangkut intelektualnya harus sesuai dengan materi keilmuan yang hendak dikuasai. Kalaupun ia dapat memperoleh ilmu itu, kemungkinan kurang bermanfaat bagi dirinya. Bagaimanapun juga, guru sangat besar peranannya dalam proses pendidikan. Seperti yang dikatakan oleh Ali bin Abi Thalib, bahwa sarat keberhasilan seorang siswa dalam belajar adalah adanya petunjuk dari seorang guru.

2. Belajar menuntut konsentrasi.

Sesuai dengan pandangan Al-Ghazali tentang tujuan pendidikan yakni mendekatkan diri pada Allah, dan itu tidak akan terwujud kecuali dengan mensucikan jiwa serta melaksanakan ibadah kepada- Nya. Beliau menyarankan agar murid memusatkan konsentrasinya terhadap ilmu yang sedang dikaji, ia harus mengurangi ketergantungannya kepada masalah keduniaan. 
3. Belajar harus didasari sikap tawadhu'.

Berkaitan dengan tugas murid dalam kegiatan belajar mengajar, Al-Ghazali menasehatkan agar murid mempunyai sikap tawadhu' dan merendahkan diri terhadap ilmu dan guru, sebagai perantara diterimanya ilmu itu.

4. Belajar bertukar pendapat hendaklah telah mantap pengetahuan dasarnya. Al-Ghazali menasihatkan kepada murid agar tidak melibatkan diri dalam perdebatan atau diskusi tentang segala ilmu pengetahuan baik yang bersifat keduniaan maupun keakhiratan sebelum terlebih dahulu mengkaji dan memperkokoh pandangan dasar ilmu-ilmu itu. Disinilah tampak pentingnya seorang guru untuk menunujukan cara belajar bagi murid. Guru yang tidak dapat dipegangi pendapatnya, apalagi hanya menebak pendapat-pendapat orang lain tanpa mengemukakan kelebihan dan kekurangannya masingmasing, ia tidak patut dijadikan pembimbing dan penasihat. Jika murid tidak mengetahui pengetahuan dasar tentang segala perdebatan maka ia akan jadi orang fanatik dalam masalah-masalah furu" sehingga sering menyalahkan pendapat orang lain. Tetapi lain halnya dengan murid yang mempunyai pengetahuan dasar penyebab perbedaan pendapat dan perselisihan paham tersebut maka ia tidak akan fanatisme terhadap madzhab atau aliran tertentu, tidak menyalahkan orang lain, apalagi sampai mengkafirkan dan sebagainya.

5. Harus mengetahui nilai dan tujuan pengetahuan yang dipelajari.

Pandangan Al-Ghazali terhadap ilmu mendasari pemikirannya mengenai bagaimana langkah terbaik dalam mengkaji suatu ilmu pengetahuan. IImu itu menurutnya mempunyai nilai yang bebeda-beda. Begitu pula tujuannya, ada yang sangat penting, kurang penting dan tidak penting.

6. Belajar secara bertahap.

Sesuai dengan pandangannya terhadap manusia bahwa ia dapat menerima ilmu pengetahuan dengan baik jika prosesnya sesuai dengan tingkat perkembangan intelektualnya, dan pandangannya bahwa ilmu itu dalam berbagai macamnya saling terkait dan saling mendukung antara satu dengan yang lainnya. Al-Ghazali menegaskan bahwa pelajar yang ingin menguasai ilmu dengan baik serta mendalam haruslah belajar secara bertahap.

7. Tujuan belajar untuk berakhlakul karimah.

Tujuan pendidikan menurut Al-Ghazali ialah mendekatkan diri kepada Allah. Beliau menasihatkan agar murid dalam belajar bertujuan menjadi ilmuan yang sanggup menyebarluaskan ilmunya demi nilai-nilai kemanusiaan. Seorang murid menurut al-Ghazali haruslah menjadi calon guru, minimal guru bagi dirinya sendiri dengan berakhlakul karimah dan keluarganya dengan menjadi uswatun khasanah. Dalam kaitannya dengan peserta didik, lebih lanjut AlGhazali menjelaskan bahwa mereka adalah makhluk yang telah dibekali potensi atau fitrah untuk beriman kepada Allah SWT. Fitrah itu sengaja disiapkan oleh Allah SWT sesuai dengan kejadian manusia, cocok dengan 
tabi'at dasarnya yang memang cenderung kepada agama tauhid (Islam). Untuk itu tugas seorang pendidik adalah membimbing dan mengarahkan fitrah tersebut agar ia tumbuh dan berkembang sesuai dengan tujuan penciptaanNya. Peserta didik hendaknya memperhatikan hal-hal sebagai berikut:

1. Belajar dengan niat ibadah dalam rangka taqarrub ila Allah, sehingga dalam kehidupan sehari-hari peserta didik senantiasa mensucikan jiwanya dengan akhlaq al-karimah sebagaimana Q.S. Al-An'am: 162 dan Q.S. Adz Dzaariyaat: 56 (Kementerian Agama RI, 2018).

2. Mengurangi kecenderungan pada duniawi dibandingkan masalah ukhrawi sebagaimana dalam Q.S. Adh Dhuhaa:4 (Kementerian Agama RI, 2018).

3. Bersikap tawadhu" (rendah hati)

4. Menjaga pikiran \& pertentangan yang timbul dari berbagai aliran.

5. Mempelajari ilmu-ilmu yang terpuji, untuk ukhrawi dan duniawi.

6. Belajar dengan bertahap atau berjenjang, dimulai pelajaran yang mudah (konkret) menuju pelajaran yang sukar (abstrak) atau dari ilmu fardhu 'ain menuju ilmu fardlu kifayah sebagaimana dalam Q.S. Al-Fath:9 (Kementerian Agama RI, 2018).

7. Belajar ilmu sampai tuntas untuk kemudian beralih pada ilmu yang lainnya, sehingga anak didik memiliki spesifikasi ilmu pengetahuan secara mendalam.

8. Memprioritaskan ilmu diniyah sebelum memasuki ilmu duniawi.

9. Mengenal nilai-nilai pragmatis bagi suatu ilmu pengetahuan, yaitu ilmu yang dapat bermanfaat yang dapat membahagiakan, mensejahterakan serta memberi keselamatan hidup dunia akhirat (Sholihin, 2001, p. 20).

\section{Manajemen Kurikulum}

Secara tradisional kurikulum berarti mata pelajaran yang diberikan kepada peserta didik untuk menanamkan sejumlah pengetahuan agar mampu beradaptasi dengan lingkungannya. Kurikulum tersebut disusun agar dapat mencapai tujuan yang telah ditentukan.

Kurikulum Pendidikan menurut Al-Ghazali yaitu kurikulum dalam pengertian sederhana berarti mata pelajaran yang diberikan kepada peserta didik untuk menanamkan sejumlah pengetahuan agar mampu beradaptasi dengan lingkungannya. Pandangan Al-Ghazali tentang kurikulum dapat diketahui berdasarkan pandangannya dalam membagi ilmu pengetahuan menjadi dua bagian besar, yaitu ilmu agama dan non-agama (Hamim, 2014), dan selanjutnya membagi ilmu pengetahuan menjadi tiga kategori besar, yaitu:

1. Ilmu yang tercela yang tidak pantas dipelajari (al-mazmum), seperti sihir, nujum, ramalan, dan lain sebagainya. 
2. Ilmu yang terpuji yang pantas untuk dipelajari (al-mahmud) yang meliputi ilmu yang fardhu'ain untuk dipelajari dan ilmu yang hanya fardlu kifayah untuk dipelajari.

3. IImu terpuji dalam kadar tertentu atau sedikit, dan tercela jika mempelajarinya secara mendalam, seperti ilmu logika, filsafat, ilahiyyat dan lain-lain.

Dari ketiga kelompok ilmu tersebut, Al-Ghazali membagi lagi menjadi dua bagian yang dilihat dari kepentingannya, yaitu:

1) Ilmu fardhu, harus diketahui oleh semua Muslim, yaitu ilmu agama.

2) IImu fardhu kifayah yang dipelajari oleh sebagian Muslim untuk memudahkan urusan duniawi, seperti: ilmu hitung, kedokteran, teknik, ilmu pertanian dan industri (Abidin Ibnu Rusn, 1998, p. 9).

Menurut Fathiyah Hasan Sulaiman (1986), yang dimaksud dari kategorisasi ketiga ilmu tersebut adalah sebagai berikut:

1. Ilmu-ilmu tercela. Yang termasuk ilmu ini dalam pandangan Al-Ghazali ialah ilmu yang tidak ada manfaatnya baik dunia maupun akhirat dan terkadang hanya membawa mudharat bagi orang yang memilikinya, maupun bagi orang lain. IImu sihir misalnya dapat memisahkan persahabatan antar sesama manusia, menimbulkan dendam, permusuhan dan kejahatan.

2. IImu-ilmu terpuji. Al-Ghazali menjelaskan bahwa ilmu ini ialah ilmu-ilmu yang erat kaitannya dengan peribadatan dan macam-macamnya. Dia membagi jenis ilmu ini menjadi dua bagian, yaitu: yang fardhu 'ain, yaitu ilmu agama dengan segala jenisnya, mulai dari kitab Allah, ibadat pokok, hingga ilmu syari"at yang kaitannya dengan apa yang harus ditinggalkan dan apa yang harus dilakukan. Sedangkan yang fardlu kifayah adalah semua ilmu yang tidak mungkin diabaikan untuk kelancaran semua urusan, seperti ilmu kedokteran, ilmu hitung dan lain-lain. Menurutnya, jika tidak ada yang mempelajari ilmu itu maka berdosalah seluruhnya, tetapi jika telah ada seseorang yang menguasainya dan dapat mempraktekkannya maka tuntutan wajibnyapun telah lepas dari yang lain.

3. IImu-ilmu yang terpuji dalam kadar tertentu atau sedikit, dan tercela jika mempelajarinya secara mendalam, karena dengan mempelajarinya dapat menyebabkan terjadinya kesemrawutan dan kekacauan antara keyakinan dan keraguan yang dapat membawa pada kekafiran, seperti ilmu filsafat. IImu ini tidaklah wajib bagi setiap orang, karena menurut tabiatnya tidak semua orang dapat mempelajari ilmu itu dengan baik. Dia berpendapat bahwa orang yang mempelajari ilmu tersebut bagai anak kecil yang masih menyusui, dan akan sakit apabila diberikan makanan yang bermacam-macam yang belum dapat dicerna oleh perutnya. Dengan demikian, dapat dipahami bahwa pada prinsipnya, Al-Ghazali lebih menekankan pada muatan ilmu-ilmu keagamaan dengan segala cabangnya dan juga ilmu-ilmu yang erat kaitannya dengan kemaslahatan manusia pada umumnya. Dia juga lebih menekankan pada segi 
pemanfaatan ilmu pengetahuan dengan berdasarkan pada tujuan iman dan taqarrub pada Allah SWT. Hal ini menjadi wajar dengan melihat latar belakang kehidupan beliau sebagai seorang sufi.

Dalam menyusun kurikulum pelajaran, Al-Ghazali memberi perhatian khusus pada ilmu-ilmu agama dan etika sebagaimana yang dilakukannya terhadap ilmu-ilmu yang sangat bermanfaat bagi kehidupan masyarakat (Ambarwati, 2018). Kurikulum menurut Al-Ghazali merupakan alat pendidikan yang hendaknya disesuaikan dengan perkembangan peserta didik (Putra, 2016). Kurikulum menurut Al-Ghazali didasarkan pada dua kecenderungan sebagai berikut:

1. Kecenderungan agama dan tasawuf. Kecenderungan ini membuat Al-Ghazali menempatkan ilmu-ilmu agama di atas segalanya dan memandangnya sebagai alat untuk menyucikan diri dan membersihkannya dari pengaruh kehidupan dunia.

2. Kecenderungan pragmatis. Kecenderungan ini tampak dalam karya tulisnya. Al-Ghazali beberapa kali mengulangi penilaian terhadap ilmu berdasarkan manfaatnya bagi manusia, baik kehidupan di dunia maupun akhirat. Dia menjelaskan bahwa ilmu yang tidak bermanfaat bagi manusia merupakan ilmu yang tak bernilai.

Bagi Al-Ghazali, setiap ilmu harus dilihat dari kegunaannya dalam bentuk amaliah. Manusia adalah subyek pendidikan, sedangkan pendidikan itu sangat penting bagi manusia, maka dalam pendidikan itu harus diperhatikan tentang kurikulumnya (Nata, 2003). Kurikulum pendidikan menurut Al-Ghazali adalah materi keilmuan yang disampaikan kepada murid hendaknya secara berurutan, mulai dari hafalan dengan baik, mengerti, memahami, meyakini, dan membenarkan terhadap apa yang diterimanya sebagai pengetahuan tanpa memerlukan bukti atau dalil (Arifin, 1991, p. 87). Pemikiran Al Ghazali tentang kurikulum dapat dipelajari dari pemikirannya tentang membagi ilmu ke dalam tiga kategori besar: (1) ilmu yang tidak layak, (2) ilmu yang layak, dan (3) ilmu yang terpuji sampai tingkat tertentu tetapi tidak direkomendasikan untuk dipelajari secara mendalam (Barni \& Mahdany, 2017).

Oleh karena itu untuk melakukan pentahapan pada kurikulum tersebut, lahirlah metode khusus pendidikan, menurut Al-Ghazali yaitu:

1. Metode khusus pendidikan agama. Metodik pendidikan agama Islam menurut Al-Ghazali, pada prinsipnya dimulai dengan hafalan dan pemahaman kemudian dilanjutkan dengan keyakinan dan pembenaran, setelah itu penegakan dalildalil dan keterangan yang menunjang penguatan akidah. Yang demikian itu merupakan pantulan dari sikap hidupnya yang shufi dan tekun beribdah. Beliau menemukan cara untuk mencegah manusia dari keraguan terhadap persoalan agama yaitu adanya keimanan kepada Allah, menerima dengan jiwa yang jernih dan akidah yang pasti pada usia sedini mungkin. Kemudian menkokohkannya dengan argumentasi yang didasarkan atas pengkajian dan penafsiran Al- 
Qur"an dan Hadist secara mendalam disertai dengan tekun beribadah, bukan melalui IImu kalam atau lainnya yang bersumber pada akal.

2. Metode khusus pendidikan ahklak. Akhlak adalah suatu sikap yang mengakar dalam jiwa sejak lahir. Ada akhlak terpuji dan tercela. Dengan adanya metode tersebut, maka Al-Ghazali menyimpulkan bahwa pendidikan itu harus mengarah kepada pembentukan akhlak mulia, sehingga dia menjadikan Alquran sebagai kurikulum dasar dalam pendidikan. Dia juga menyimpulkan bahwa tujuan akhir pendidikan dan pembinaan itu ada 2 yaitu:

1) Kesempurnaan yang bermuara pada pendekatan diri kepada Allah.

2) Kesempurnaan yang bermuara pada kebahagiaan dunia dan akhirat.

Selanjutnya terkait dengan evaluasi pendidikan. Menurut AI Ghazali, evaluasi pendidikan berarti usaha memikirkan, membandingkan, memprediksi menimbang, mengukur, dan menghitung segala aktifitas yang telah berlangsung dalam proses pendidikan, untuk meningkatkan usaha dan kreativitasnya sehingga dapat seefektif dan seefisien mungkin dalam mencapai tujuan yang lebih baik diwaktu yang akan dating (Al-Ghazali, 2003).

Adapun subyek evaluasi pendidikan adalah orang yang terikat dalam proses kependidikan meliputi: pimpinan, subyek didik, wali murid, dan seluruh tenaga adminstrasi. Dan juga yang menjadi evaluasi pendidikan adalah semua bentuk aktivitas yang terkait dengan tugas tanggung jawabnya masing-masing dalam proses kependidikan. Tujuan evaluasi pendidikan tersebut ialah mengontrol efektifitas dan efisiensi usaha dan sarana, mengetahui segi-segi yang mendukung dan menghambat jalannya proses kependidikan menuju kepada tujuan yang ingin dicapai (Zainuddin, 1991, pp. 42-43).

\section{PENUTUP/SIMPULAN}

Berdasarkan pembahasan pada artikel terkait konsep pendidikan Islam dalam perspektif Al-Ghazali yang meliputi manajemen pendidikan, manajemen peserta didik, dan manajemen kurikulum, dapat disimpulakn beberapa hal yang fundamental. Al-Ghazali atau Muhammad bin Muhammad bin Muhamad bin Ahmad Al-Ghazali merupakan tokoh pendidikan Islam yang sudah tak diragukan lagi kemampuannya dalam bidang pendidikan Islam. Pendidikan Islam dalam pandangannya merupakan proses memanusiakan manusia sampai akhir hayatnya menuju pendekatan diri kepada Allah sehingga menjadi manusia sempurna. Metode yang digunakan dalam pendidikan yaitu dimulai dengan hafalan dan pemahaman kemudian dilanjutkan dengan keyakinan dan pembenaran. Pendidikan apapun, menurut Al-Ghazali harus mengarah kepada pembentukan akhlak yang mulia.

Menurut pandangannya, peserta didik yang dimaksud ialah murid. Al Ghazali menguraikan hal-hal yang harus dipenuhi murid dalam proses belajar mengajar yaitu, belajar merupakan proses jiwa, belajar menuntut konsentrasi, belajar harus didasari sikap tawadhu'. Sementara kurikulum pendidikan menurut Al-Ghazali yaitu 
kurikulum dalam pengertian sederhana yaitu mata pelajaran yang diberikan kepada peserta didik untuk menanamkan sejumlah pengetahuan agar mampu beradaptasi dengan lingkungannya. la memberi perhatian khusus pada ilmu-ilmu agama dan etika serta didasarkan pada dua kecenderungan: kecenderungan agama dan tasawuf; dan kecenderungan pragmatis.

\section{UCAPAN TERIMA KASIH}

Ucapan terima kasih sedalam-dalamnya dan penghargaan yang setinggi-tingginya kepada seluruh pihak yang telah membantu proses penerbitan artikel ini. Ucapan terima kasih secara khusus penulis sampaikan kepada Rektor UIN Alauddin Makassar selaku pimpinan tempat dimana penulis melaksanakan aktifitas seharihari sebagai Aparatur Sipil Negara.

\section{DAFTAR PUSTAKA}

Abdullah, M. A. (2002). Antara al-Ghazali dan Kant: Filsafat Etika Islam, (Terj) (Cet.I). Bandung: Mizan.

Al-Ghazali. (1969). Ihya' al-Ghazali, Jilid I (Cet.4). Surabaya: Faizan.

Al-Ghazali. (2003). Tahafut al-Falasifah. Yogyakarta: Islamika.

Ambarwati, R. (2018). Konsep Pendidikan Islam Perspektif Al-Ghazali dan Syed Muhammad Naquib Al-Attas (Studi Komparasi). Institut Agama Islam Negeri Ponorogo.

Arifin, H. M. (1991). Filsafat Pendidikan Islam (Cet.I). Jakarta: Bumi Aksara.

Arista, R. N. (2019). Konsep Pendidikan Menurut Al-Ghazali dan Relevansinya dalam Pendidikan di Indonesia. Jurnal Tawadhu, 3(2), 883-892.

Bakar, O. (1997). Hierarki Ilmu. Bandung: Mizan.

Barni, M., \& Mahdany, D. (2017). Al Ghazali's Thoughts on Islamic Education Curriculum. Dinamika IImu, 17(2), 251-260.

Fad, M. F. (2019). Kategorisasi Pencari IImu. Harian Suara Merdeka.

Fathiyana, L. (2011). Konsep Guru yang Ikhlas Menurut Imam Al-Ghazali dalam Kitab Ihya' Ulumuddin. Institut Agama Islam Walisongo Semarang.

Hamim, N. (2014). Pendidikan Akhlak: Komparasi Konsep Pendidikan Ibnu Miskawaih dan Al-Ghazali. Jurnal Studi Keislaman, 18(1), 21-40.

Kementerian Agama RI. (2018). al-Qur'an dan Terjemah. Pustaka Al-Kautsar: Jakarta.

Mundiri, A., \& Bariroh, A. (2018). Amplifikasi Profesi Guru dalam Proses Pendidikan Transformatif Perspektif Al-Ghazali. Jurnal IImiah Islam Futura, 18(1), 159184. 
Nata, A. (2003). Pemikiran Para Tokoh Pendidikan Islam Seri Kajia Filsafat Pendidikan Islam. Jakarta: PT. Raja Grafindo Persada.

Nisa', K. (2016). Al-Ghazali: Ihya' Ulum Al-Din dan Pembacanya. Jurnal Ummul Qura, VIII(2), 1-15.

Nizar, S. (2002). Filsafat Pendidikan Islam, Pendekatan Historis, Teoretis, dan Praktis. Jakarta: Ciputat Press.

Putra, A. A. (2016). Konsep Pendidikan Agama Islam Perspektif Al-Ghazali. Jurnal AlThariqah, 1(1), 41-54.

Ramayulis. (2006). IImu Pendidikan Islam. Jakarta: Kalam Mulia.

Rusn, Abidin Ibn. (1999). Pemikiran Al-Ghazali tentang Pendidikan. Yogyakarta: Pustaka Pelajar.

Rusn, Abidin Ibnu. (1998). Pemikiran al-Ghazali Tentang Pendidikan (Cet.I). Yogyakarta: Pustaka Pelajar.

Setiawan, E. (2017). Konsep Pendidikan Akhlak Anak Perspektif Imam Al Ghazali. Jurnal Kependidikan, 5(1), 43-54.

Sholihin, M. (2001). Epistimologi IImu Dalam Sudut Pandang al-Ghazali (Cet.I). Bandung: Pustaka Setia.

Sulaiman, F. H. (1986). Konsep Pendidikan Al-Ghazali. Jakarta: Guna Aksara.

Sulaiman, F. H. (1993). Aliran-Aliran Dalam Pendidikan Studi Tentang Aliran Pendidikan Menurut Al-Ghazali (Cet.I). Semarang: Dina Utama.

Suryadarma, Y., \& Haq, A. H. (2015). Pendidikan Akhlak Menurut Imam Al-Ghazali. Jurnal At-Ta'dib, 10(2), 361-381.

Syadani, A. (1997). Filsafat Umum. Bandung: Pustaka Setia.

Syarif, Z. (2018). Dinamisasi Manajemen Pendidikan Pesantren: Dari Tradisional Hingga Modern (Duta Media). Pamekasan.

Tafsir, A. (1992). IImu Pendidikan dalam perspektif Islam. Bandung: Rosdakarya.

Wahyudi, I., \& Rouf, A. (2012). Konsep Pendidikan Manajemen dalam Perspektif AlGhazali. Yogyakarta: Leutikaprio.

Wartini, A. (2015). Education Character in View of Al-Ghazali and Its Relevance with the Education Character in Indonesia. Ta'dib, 20(2), 293-310.

Zainuddin. (1991). Seluk Beluk Pendidikan dari Al-Ghazali. Jakarta: Bumi Aksara 